\title{
ABSTRACT: The Mapping of Meaning
}

As the second of two linked papers, this piece further advances the interpretation of the text in a state of process and as a published work through the analysis of literary speech acts. It does so by exploring the place-specific nature of the spatialised speech act, for which a particular geographical location is central to meaning in multiple ways. Theoretically, the paper draws upon the work of Merleau-Ponty and Michel de Certeau. Textually, it explores such ideas through Wordsworth’s poem “Michael” considered across all its textual states.

The paper is in five sections. The first, “Theorising Spatiality”, establishes a basis for considerations of space and place using the theorists already mentioned, before the second section moves on to attempt to define "textual place" and "textual space”. These concepts are then explored through a discussion of the material relationship between Wordsworth and Coleridge, "Michael” and Christabel, in surviving drafts and copied texts as well as in the relationship between geographical place and compositional place for the writing of "Michael”. The fourth section returns to the published work of art as well as to a close focus on the spatialised speech act, centring analysis on Michael's covenant. The final part of the paper begins to explore ideas of "mapping" in terms of readerly inhabitation of space, with particular reference to the mapping of manuscripts. Throughout, theoretical and textual ideas are grounded in close analysis of the poem itself in different manifestations.

The paper hopes to illustrate more generally the potential of a spatialised approach for Literary Studies but also the value of a spatial approach for Romantic textuality, through its capacity to allow free movement across and between the text in a fixed, published, state and the text in a state of process. 
SALLY BUSHELL

\section{The Mapping of Meaning in Wordsworth's "Michael": (Textual Place, Textual Space and Spatialised Speech Acts)}

This paper is the second of two pieces concerned with the application of speech act theory to the critical analysis of draft materials. ${ }^{1}$ Where the first paper explored the differences between a speech act in the world, a speech act for the literary work of art and speech acts within textual process, this paper adopts a more spatialised approach. In that previous paper I explored the doubled nature of the speech act as "a saying and an enacted doing" and outlined a mode of interpretation emerging out of the making of meaning. The spatialised speech act concerns saying and enacted doing in a temporal and physical location which bears upon meaning: it introduces specific elements of time and space, allowing for multiple layerings of meaning over time. This paper, then, seeks to argue that a spatialised account of literary speech acts enables interpretation to connect different kinds of speech act, on the manuscript page, in the published work and in the lived worlds of writer and reader. In particular, I am interested in how a spatialised understanding in which "Being is synonymous with being situated" offers potential for an interpretational model that moves between the spatiality of a made text and a text in the making. ${ }^{2}$ Wordsworth's poem "Michael" allows us to explore the multiple ways in which the space and place of the literary work bear upon meaning, affecting the text across all its states.

Theorising Spatiality: Maurice Merleau-Ponty and Michel de Certeau

In his Phenomenology of Perception, instead of thinking of space as a setting or background for things, Merleau-Ponty defines it as "the universal power enabling them to be connected" (PP 284) and describes three ways of understanding space. The first, "physical space", corresponds to a traditional objective account, in which body and

1. See Bushell, "The Making of Meaning in Wordsworth's Home at Grasmere: (Speech Acts, MicroAnalysis and 'Freudian Slips')," Studies in Romanticism (Fall, 2009).

2. Maurice Merleau-Ponty, The Phenomenology of Perception, 1945, (henceforth PP) trans. Colin Smith (London and New York; Routledge, 1962) 294. 
things are understood in terms of their empirical relations; the second, "geometrical space", corresponds to a subjective account in which space is intellectualized so that things "live only through the medium of a subject who traces out and sustains them" (PP 284). Both of these accounts, however, fail to allow for the actual perception of space: "Intellectualism and empiricism do not give us any account of the human experience of the world; they tell us what God might think about it" (PP 298). Against these definitions Merleau-Ponty articulates a "third spatiality . . . which is neither that of things in space, nor that of spatializing space" (PP 289). This spatiality is defined in terms of experience: the virtual body is held in a phenomenal space of projected actions which connect the actual body to the world but in which both are equally bound together: "What counts for the orientation of the spectacle is not my body as it in fact is, as a thing in objective space, but as a system of possible actions, a virtual body with its phenomenal 'place' defined by its task and situation" (PP 291). This leads MerleauPonty back to his central claim, already quoted, that "Being is synonymous with being situated" (PP 294). Thus, instead of a conception of space as entirely "outside" or "inside" the subject, it is now to be understood in terms of a dynamic relationship in which being and world meet reciprocally: "'Dynamic phenomena' take their unity from me who live through them, and who effect their synthesis" (PP 317). Towards the end of his chapter on "Space", Merleau-Ponty defines this phenomenological understanding in terms of "human space" ("l'espace anthropologique") which can be most clearly seen in human activities with no empirical base, such as dreams, emotions, and myth. ${ }^{3}$

Merleau-Ponty's account has provided a richly suggestive starting point for spatial theorists such as Gaston Bachelard and Michel de Certeau. It is to Merleau-Ponty's definitions that Michel de Certeau refers when he builds on a central distinction between "geometrical" and "anthropological" space in The Practice of Everyday Life, privileging the latter. He states:

I shall try to locate the practices that are foreign to the "geometrical" or "geographical" space of visual, panoptic, or theoretical constructions. These practices of space refer to a specific form of operations ("ways of operating"), to "another spatiality" (an "anthropological," poetic and mythic experience of space),

3. Maurice Merleau-Ponty, Phénoménologie de la perception (Paris: Gallimard, 1945) 335. 
and to an opaque and blind mobility characteristic of the bustling city. A migrational, or metaphorical, city, thus slips into the clear text of the planned and readable city. ${ }^{4}$

Here Certeau's bringing together of Foucault and Merleau-Ponty in his conceptualisation of controlled space is strongly felt, as is the extent to which his account of spatial acts in the city is founded upon Merleau-Ponty's prior definitions (acknowledged by him in a footnote). His use of literal metaphorai (PEL 115)- imagined conceptions of space which are embodied, and even unknowingly expressed, through transgressional movement - emerges directly from Merleau-Ponty's earlier account, but takes it forward through an exploration of the power of narrative and oral stories to work against a dominant imposed space.

As is well known, in The Practice of Everyday Life, Certeau adopts the doubled structure of the speech act to explore a relationship between (individual) tactics and (system-created) strategies across different kinds of spatial practice centred upon strategies of "enunciation". A "strategy" involves the larger forces of power ("the organizing techniques of the system" [PEL 34]) whilst the "tactic" concerns every day practices and events experienced by those held within the strategic forces. Tactics have the power (through memory and narrative) to unknowingly undo the dominance of the strategic space, but they only come into being and define themselves through resistance to it. A strategy seeks to control and fix space over time, it "postulates a place that can be delimited as its own" (PEL 36) whereas a tactic is temporally immediate and "is the space of the other. . . . it must play on and with a terrain imposed on it" (PEL 37).

Certeau himself remains primarily interested in the functioning connection between the two - in particular in the way in which operations enacted by the user ("ways of making" $[P E L \mathrm{xv}]$ ) redefine what they act upon. ${ }^{5}$ The conversion of place to space (the empowerment of the tactic) occurs through the various cultural practices that Certeau addresses, but above all through oral stories as the "cultural lifeblood of any social

4. Michel de Certeau, The Practice of Everyday Life (henceforth PEL) trans. Stephen Rendall (Berkeley: University of California Press, 1985) 93.

5. Michel de Certeau emphasises from the outset that his concern lies with examining the practices of users as consumers. He is thus interested in one kind of "making" only - that of the experience involved at the time of participation in an act. In literary terms, he is interested in the "making" of the act of reading ("silent production"), but not in the "making" of the act of writing. 
environment" which create an active spatial force linking people to each other and to places in unpredictable ways. ${ }^{6}$ In the sections of this paper that follow I will draw upon Certeau's spatial account of speech acts in the world in three ways: to make a distinction between "textual place" and "textual space" for the reading of manuscripts and apply this to interpretation of materiality in "Michael" mss; to explore the concept and function of spatialised speech acts at a level of representation within the literary work of art; and to consider what is revealed by a "mapping" of manuscripts in relation to "Michael".

\section{Defining Textual Place and Textual Space}

Michel de Certeau's definitions of "place" and "space" conform to the larger distinction which structures his entire study (between system and user, strategy and tactic). Although he makes this terminological distinction (which Merleau-Ponty largely tries to avoid), Certeau is not imposing an absolute subject/ object division since his account of "space" functions in terms of lived experiences connecting the individual to the world but with the power to shape and change the place in which they occur. Thus, there is potentially a two-way interaction between place and space. Place is associated with "the law of the 'proper"' by which things are fixed and specifically located, in an attempt to create "an instantaneous configuration of positions" (PEL 117) so that Certeau's "place" corresponds to both "physical" and "geometrical space" in Merleau-Ponty's terms. By contrast space is mobile, involving direction, speed and time and "actuated by the ensemble of movements deployed within it"(PEL 117). Ways of operating define and create "human" space within place, which leads Certeau famously to conclude that: "space is a practiced place" (PEL 117).

The distinction applies not only to physical movement through the world, but also to other cultural acts, including that of reading. Thus Certeau asserts that:

The street geometrically defined by urban planning is transformed into a space by walkers. In the same way, an act of reading is the space produced by the practice of a particular place" (PEL 117) 
When he turns his attention to the practice of reading, unsurprisingly, Certeau is far more interested in the tactics of the ordinary reader than the strategic attempts of the author/writer (or, it must be said, the elitist activities of the literary critic) just as he is far more interested in the making of the reader-consumer than the making of the authorproducer. When Certeau briefly discusses the author he describes him as someone who "in effect denies his real situation" and "creates the fiction of a place of his own" (PEL 44). In other words, the author is on the side of the producer, seeking to create a lasting strategic control of space. By contrast the activity of reading is temporally immediate, occurring within the apparent discipline of the authorial text. It has:

all the characteristics of a silent production: the drift across the page, the metamorphosis of the text effected by the wandering eyes of the reader. . . . But since he is incapable of stockpiling . . . the reader cannot protect himself against the erosion of time ... (PEL xxi)

The reader re-appropriates the space of the text for him or her self: "he poaches on it, is transported into it" until "This mutation makes the text habitable, like a rented apartment" (PEL xxi).

It is important to acknowledge the dangers of assuming a dualistic distinction between place and space. ${ }^{7}$ In my attempt to denote "textual place" and "textual space" below, I want to follow Certeau in allowing that "readerly" experience of space can redefine "writerly" place but I also want to problematise some of the ideas raised by his work when considered in relation to the three dimensions of the manuscript object (as a thing; as a sequence of acts upon the page; as a literary work of art). Certeau might see the published, authorial text as a form of power (strategy) against which to set the tactic of "reader as poacher". However, spatialised speech acts are present not only for the reader reading a text but also for the writer writing it and re-reading it (especially for the

7. Certeau's model appears dualistic but is not, in part because both place and space are experienced in the world (the third element) but also because of their ability to change each other. Merleau-Ponty's account (itself looking back to Heidegger) allows for three kinds of space that could also be compared to Henri Lefebvre's three notions of a "perceived space" (everyday), "conceived space" (theoretical) and "lived space" (fully experienced) in The Production of Space (trans. Donald Nicholson-Smith [Oxford: Blackwell, 1991]); and Edward Soja's "trialectic" which seeks to connect the human dimensions of spatiality, historicality and sociality (Thirdspace: Journeys to Los Angeles and Other Real-And-Imagined Places [Oxford: Blackwell, 1996]). I have not used these theorists here, since my focus was on speech acts, and also because their primary interest is in socio-political rather than literary space. 
text in a state of process). Could one not therefore see the writer, writing, as a "tactician" seeking to create space for his own voice within the dominant language structure? Could one not view the surviving draft materials of a text in a state of process as a kind of resistant meaningful narrative, paradoxically set against the dominance of the final text that they will, cumulatively, bring into being? To what extent is Certeau's pleasing account of "reader as poacher" problematised by the "uninhabitable" space of the manuscript page and the need to map and journey through this space differently from that of a published work of art?

It is time to attempt my own definitions of textual place and textual space, before applying a spatialised understanding of the literary work of art to a reading of the manuscripts of "Michael". I want to begin by defining textual place. This, I would suggest, is concerned with the materiality of the manuscript or published book as a tangible object - a thing in the world that allows multiple temporal and physical connections to it. It has a doubled identity in terms of our response to both the material form of the manuscript or book, and to the entry of text upon it, the nature of print or handwriting on the page. Thus we can respond to it in terms of its physicality (dimension, weight, smell, colour and so on) but we can also respond to it as a place invested with written marks. For the manuscript, it holds the writer's creative acts as marks upon the page shaped by a particular hand, which both occur within a certain place, and bring it fully into being (since the material object alone, without writing upon it, cannot be defined as "textual"). Textual place constitutes a specific site, a location. It is literal, unique and (crucially) non-reproducible. ${ }^{8}$ It can be re-visited, just as a geographical place can and it can thus be mapped and journeyed through. For the later reader, it is always already there: the placeness of the page cannot be altered. ${ }^{9}$ Textual place is not conceptual, but tangible: it is of the world. In terms of meaningful interpretation, however, by itself, this dimension of the literary work is relatively limited. It is the understanding of textual space in and through textual place (through the

8. For the manuscript each page is unique because of its materiality. For a printed book, even though it is mass-produced, it also exists as an individual physical object, acquiring its own unique materiality (faded in the sun, annotated, coffee-stained etc.).

9. Although a personalised materiality can also accrue (see note above). 
meaningful activities of writer and reader) which makes sense of the object as a literary work of art.

Textual space, by contrast, is reproducible - not singular - and free, not fixed. At its simplest it can be understood in terms of the content of the text; its semantic and syntactic meaning. It stands for the open dimension of the literary work of art which can be experienced and re-experienced over time. It is multiple and layered and could be understood as primarily "readerly". Textual space extends across different versions of the draft text, into its manifestation as a final published work. Through the act of reading it is then able to be re-inhabited in an open-ended way. It is theoretically boundless, but in practice our experience of it is always delimited, in different ways. If textual place corresponds to Merleau-Ponty's "physical" space, then textual space seems to require a degree of "geometrical" presentation (mapping and situating) before the reader can be fully released into a "human" lived experience of the literary work. To understand any single aspect, in our reading of draft or completed texts, we have to draw upon different kinds of spatial awareness.

As we shall see in relation to "Michael", textual space ultimately allows for an extraordinary freedom of movement on the part of the reader, connecting geographical place in the world to literary and imaginative space and potentially enabling effects within the text to radiate outward. This textual space is fully "inhabitable" by the reader. The textual space of draft materials, however, functions very differently and demands a different kind of engagement because its identity is bound up with meaning and it is thus affected by whether the text attempts to present unified meaning or not. Within draft materials, textual space does not unfold in a continuous and unified way but repeats itself, doubles back, loses direction. This has significant implications for both writerly and readerly inhabitation of it and the way in which we "map" it. The material holds within it different temporalities which the reader must respect if the marks on the page are to make sense. There are three major distinctions to be made: between the writer first writing (the past "now" of initial acts on the page); the writer re-reading and rewriting; and the later reader (who will exist in a number of historical manifestations from "first reader" onwards). These distinctions are important because they partly undo, or at least problematise, the distinction between the Author's "proper" place and the 
"tactics" of the reader, in relation to draft materials. Whilst the thing made may well attempt to present a fixed, stable, front to the world, the making of the thing does not need to do so, with the result that writerly acts within the draft materials partake more of the "tactic" than the "strategy" (although ultimately the larger aim may still be towards the "proper" space of a published work). Such a discussion also reminds us of one other crucial point: that for the literary work of art both textual place and textual space are preceded by imaginative anticipation of written text. Words in the mind, or on the tongue, are held in a pre-textual space which itself may or may not draw upon prior experience of geographical place or other textual spaces. ${ }^{10}$

The distinction I am making between "textual place" and "textual space" could be compared to that made between "document" and "text" by textual critic, Paul Eggert. ${ }^{11}$ He makes a distinction between "material object -or what I prefer to call document" (2) and text which "requires the socialized reader's engagement in the raising of meaning from the document" (2). How does it help us to think about such concepts in spatial terms rather than in terms of the material or immaterial nature of the work? We might say that just as text is raised from the document, so written and represented speech acts on the manuscript or printed page link textual space to textual place, meaning to materiality, readerly acts to writerly acts and the present experience of the object to the past moment(s) of its coming-into-being. A spatialised account, drawing upon Certeau, allows for interaction between these two dimensions as an essential part of understanding and interpreting both of them. We need to explore such ideas further through the manuscripts for "Michael".

\section{Spatialising the Writing of Michael}

Wordsworth's pastoral poem, "Michael", was written, copied and sent off for publication in two months between October $11^{\text {th }}$ and December $18^{\text {th }}, 1800$. Surviving manuscripts exist in four different states: fragments of rhyming text in DC MS 15; draft and fair copy

10. My thanks to Jim Mays for making this point when I presented an early version of this work at the Annual Symposium on Textual Studies, De Montfort University, May 2008.

11. Paul Eggert, "Document and Text: The 'Life' of the Literary Work and the Capacities of Editing," TEXT 7 (1994): 1-14. See also Eggert's recent book: Securing the Past: Conservation in Art, Architecture and Literature (Cambridge, CUP, 2009) particularly the final chapter. 
towards "Michael" and related material that became "The Matron's Tale" in DC MS 30; fair copy in DC MS 31 for which "A full text of Michael may have stood at the back of the notebook on much of two gatherings now removed (stubs 88-74)"; and the Printer's Copy, MS.1800. ${ }^{12}$ Alongside this material record we are fortunate to have a detailed factual summary of dates and times of composition provided by Dorothy's Journal.

"Michael" was written under pressure, created by the decision made on October $6^{\text {th }}$ to remove "Christabel” from the second volume of the 1800 Lyrical Ballads: "Determined not to print Christabel with the LB". ${ }^{13}$ Composition could not have begun before this decision was made, but soon after this, on October $11^{\text {th }}$, William and Dorothy set out on a walk in search of a sheepfold, an action that seems likely to have been undertaken as a stimulus for writing the poem: ${ }^{14}$

A fine October morning - sat in the house working all the morning. Wm. composing - Sally Ashburner learning to mark. After Dinner we walked up Greenhead Gill in search of a Sheepfold. . . The Colours of the mountains soft \& rich, with orange fern - the Cattle pasturing upon the hill-tops Kites sailing as in the sky above our heads - Sheep bleating \& in lines \& chains \& patterns scattered over the mountains. They come down \& feed on the little green islands in the beds of the torrents \& so may be swept away. The Sheepfold is falling away it is built nearly in the form of a heart unequally divided. (26)

It is reasonable to assume that composition began at around this time. Wordsworth then worked steadily, although unsuccessfully, on the poem through to November $9^{\text {th }}$ at which point he destroyed at least part of what he had written. In the Journal the first phase of unsuccessful writing is recorded in detail, whilst the second phase of writing, which was much more successful and clearly quite intense, is hardly mentioned until, on December $9^{\text {th }}$, Dorothy declares "Wm finished his poem today"(35). On December $10^{\text {th }}$ a copy of the completed poem was begun and this was sent off to the printer on the 18th.

12. James Butler and Karen Green, eds., Lyrical Ballads and Other Poems, 1797-1800 by William Wordsworth (henceforth LB) (Ithaca and London: Cornell University Press, 1992) xxvi.

13. Pamela Woof, ed., Dorothy Wordsworth: The Grasmere and Alfoxden Journals (henceforth Journal) (Oxford: OUP, 2002) 24.

14. In Wordsworth, The Chronology of the Middle Years (henceforth CMY) (Cambridge, Massachusetts: Harvard University Press, 1975), Mark Reed notes that: "The search for the sheepfold on 11 Oct would appear to indicate an already established interest most readily explained by work on or thought about a poem like Michael" (91). 
I have selected "Michael" as a work for which spatial issues bear upon meaning in multiple ways, affecting the text across all its states and meaningful aspects. I want to look at two of these here in relation to the making of the poem's meaning: firstly, the relationship between William and Samuel, "Michael" and “Christabel”, as it is played out in material terms, and secondly the relationship between geographical place and textual place for the writing of "Michael".

The first textual place to assert itself (prior to any written composition) is that of the gone-to-press text of an already-printed collection, awaiting a poem of a certain ambition, physical length and genre in order to be published. In a letter sent with the Printer's Copy of "Michael" on $18^{\text {th }}$ December, Wordsworth's comments make clear his alertness to the dimensions of the yet-to-be-published book, as well as to the meaning held in the arrangement of the collection:

This poem contains 493 or 4 lines. If it be sufficient to fill the volume to 205 pages or upwards, printing it at 18 lines, or never more than 19 in a page as was done in the first Edition of Lyrical Ballads you will print this poem immediately after the Poems on the Naming of places and consider it as . . f finishing the work. . . . I wish it to conclude the volume. ${ }^{15}$

In view of the empirically-specific writing requirements to which Wordsworth was working it is not surprising that initial composition for "Michael" was extremely problematic, as we shall see below.

There can be little doubt that the removal of "Christabel" from the 1800 volume, even if it was a mutual decision at the time, and even if justified on the grounds of length, genre and poetic principle, had an extremely negative short and long-term effect on Coleridge. ${ }^{16}$ The psychobiographical implications of the relationship between Wordsworth and Coleridge, in 1800 have been discussed by various critics. Of particular relevance here is Susan Eilenberg's reading of "Michael" as "a work of usurpation" which "acts simultaneously to suppress and supplant, to revise and to

15. Letters of William and Dorothy Wordsworth: Early Years ed. Ernest de Selincourt, $2^{\text {nd }}$ ed. rev. Chester L. Shaver (Oxford at the Clarendon Press, 1967) 307.

16. Earl Leslie Griggs notes that "Coleridge accepted this decision with apparent equanimity, but subsequent letters show that the exclusion of Christabel increased in him a sense of his shortcomings as a poet" (Collected Letters of Samuel Taylor Coleridge, ed. Earl Leslie Griggs [Oxford at the Clarendon Press, 1956]), I, 631, n.2; whilst Butler and Green comment that Coleridge "generously devoted himself to Lyrical Ballads in the summer of 1800, but his own creative flow seemed blocked" (LB 30). 
memorialize Coleridge's poem". ${ }^{17}$ She makes a number of good points about the interaction of property, propriety and possession in the two texts, asserting that for Lyrical Ballads "Coleridge's poems simply did not belong there" (89) and presenting an interesting case for the idea that "Michael's 'property' can be said to be a conceptual pun on "Christabel's 'possession'" (106). Whilst her work largely explores such issues at a thematic level it is interesting to take such ideas forward in terms of the material relation between texts and writers for the production of "Michael". I am interested in the way in which the identity of the manuscript as an object in the world, but also one with its own unfolding textual place, becomes the focal point of intersubjective tension for those entering material into it.

DC MS 15 contains the earliest work towards "Michael" in the form of a rhyming ballad and, possibly, some blank verse lyric passages which may feed into the poem indirectly. Some of the lines in "Ballad Michael" are, arguably, a light-hearted description of Coleridge or of Wordsworth and Coleridge as "Two shepeherds ... the wits of the dale". ${ }^{18}$ As interesting, however, is that this material occurs before and between the copying of "Christabel" into the same notebook, an act which took place about a year later. ${ }^{19}$ The discovery of pages of "Ballad Michael" in DC MS 15 was a source of embarrassment to earlier critics; Stephen Parrish notes that "Helen Darbishire expressed shock and disbelief when she was shown these stanzas in 1959". ${ }^{20}$ By contrast, the manuscript of "Christabel" has relatively high status within the surviving Coleridge corpus as MS 3, an early copy of a poem which does not survive in any rough draft states and which may have been dictated by the poet himself. ${ }^{21}$ Although the "Christabel" draft is entered into DC MS 15 at a later time, it clearly took priority in the Wordsworths' use of the notebook, since physical evidence reveals that the interrupting pages of blank verse fragment were sewn together into one block, improving the

17. Susan Eilenberg, Strange Power of Speech: Wordsworth, Coleridge and Literary Possession (Oxford: Oxford University Press, 1992) 97, 87.

18. DC MS 15, 94 . See also LB, 396-97 and 464-65.

19. "Ballad Michael" was probably entered in October 1800 as early work towards "Michael" whilst the Christabel copy was made some time after $6^{\text {th }}$ November 1801 . See Reed, CMY 615-616.

20. Stephen Maxfield Parrish, The Art of the Lyrical Ballads (Cambridge, Massachusetts: Harvard University Press, 1973) 154.

21. See Collected Works of Samuel Taylor Coleridge: Poetical Works, ed. J. C. C. Mays (Princeton University Press, 2001) Vol. II Part 1, 610. 
material fluency of the long poem around it. Within the context of this manuscript, then, "Christabel" triumphs over "Michael". Even though the notebook contains a large number of other texts, including many poems for Lyrical Ballads, DC MS 15 is commonly referred to as "The Christabel Notebook", a title which is also written on its cover. This occurs because the two kinds of material perform a different function according to their relative temporalities. The "Michael" material only has a brief period of writerly value before becoming rejected early draft for a work that was published in 1800. The copy of "Christabel" has no creative value within the notebook, being a mere transcription, but was nonetheless the most important item in it, presumably because it was the Wordsworth's only copy of this unpublished text. In other words, its "readerly" value asserts itself over the "writerly" value of the previous draft. Such a reading also reveals the changing meaning of the manuscript object over time. Once "Christabel" had been published (in 1816) presumably the status of the manuscript altered again and it now became more of a nostalgic object standing for a particular time in the life of the household. Centuries later, the textual place of the object holds all of these changing values within it but now asserts itself primarily as a high cultural object of significant monetary value, worthy of facsimile reproduction, scholarly editing and literary-critical discussion.

Against the material relationships of DC MS 15 in which Coleridge's text seems to dominate, we can set that of DC MS 30 for which the emphatic materiality of the author's (Coleridge's) "proper" place and space - the made book - appears to be undone by the re-appropriation of it as Wordsworth's text in the making. "Michael" (DC MS 30), and Home at Grasmere (DC MS 28), are materially-linked manuscripts, both entered over separate (unbound) sections of an interleaved copy of Coleridge's Poems on Various Subjects, (1796). In both, the published pages of Coleridge's collection are faced by Wordsworthian manuscript draft which often overwrites the printed text. We need to consider the status of the interleaved volume in terms of the relationship between Wordsworth and Coleridge in 1800. Why was the book prepared in this way and how did it come into Wordsworth's possession?

Upon publication of his Poems on $16^{\text {th }}$ April, 1796, Coleridge sent copies of the book to many of his friends but does not appear to have sent Wordsworth a copy. No doubt 
this reflects the fact that their friendship was in its very earliest stages and that Wordsworth was not yet a dominant influence. The interleaved copy (with blank pages inserted between printed ones) came about probably in order to enable Coleridge to make revisions in the 1796 volume for the 1797 reprint. Butler and Green tell us that, "the interleaving generally bears the signs of professional labour" ( $L B$ xxvi).$^{22}$ It is possible that one interleaved copy was originally sent or given to Wordsworth so that his comments on individual poems and lines could be returned to Coleridge. ${ }^{23}$ The anticipated relationship between Wordsworth's handwriting and Coleridge's print, then, could have been one in which the blank pages were filled with Wordsworth's careful reading and response to Coleridge's poems, creating a relationship in which Wordsworth's handwriting would be clearly subsidiary. Instead of this, they were filled four years later by Wordsworth's own draft poetry, transforming the book object back into a manuscript.

Early draft for "Michael" (DC MS 30) was entered on pages 33-64 of the interleaved copy in late 1800. The middle part of the unbound book is now lost. Then, either also in 1800 or in 1806, Home at Grasmere draft (DC MS 28) was entered on pages 131$175 .^{24} \mathrm{~A}$ clear pattern of spatial entry emerges across the two manuscripts. The dominant place of entry for Wordsworth's handwriting is usually the (blank) interleaved page. Printed pages are used sometimes for drafting prior to the interleaf, which is then written up on that page, and sometimes as overflow from it, with revision spilling across. For this reason, quite a number of printed pages are left blank, as Wordsworth moves directly on from one interleaved page to the next within each manuscript. When the printed page is written on, the handwritten text is often entered above and below

22. In early 1796 when Wordsworth sent the manuscript of "Salisbury Plain" to him for comment, Coleridge interleaved the text in order to respond to it, suggesting that it was a practice familiar to him at this time. In a letter from Azariah Pinney to Wordsworth of 26th March, 1796, he states that "I understand he has interleaved it with white paper to mark down whatever may strike him as worthy your notice" (Mary Moorman, William Wordsworth: A Biography, The Early Years 1770-1803 [Oxford at the Clarendon Press, 1957]) 291. A second interleaved copy of Poems (1796) in the British Library (MS Ashley 408) bears the same watermark and date for the interleaved pages as DC MSS 30 and 28, strongly suggesting that the two books were made at the same time.

23. Coleridge might have sent the interleaved text to Wordsworth at any time between January and June 1797 (possibly after Wordsworth's visit to him in late March). See also Robert Woof's comment at n.27 below.

24. The Home at Grasmere draft is generally understood to have been written four years later, as part of a coherent stage of work towards MS B in 1806. However, the manuscript contains rough draft material and so could well have been written earlier. 
printed words or along the bottom and up the margin, at right angles, respecting the print by writing on the blank spaces around it, but sometimes it is written over it.

The inscription of the text of one writer over that of another, creates a fascinating intertextual relationship, and one which can certainly be explored in ways which connect biographical, psychological and spatial meanings through the material object. In terms of the relations between Wordsworth and Coleridge in 1800, the relationship between the two texts initially lends itself to being interpreted as a violent act of appropriation by Wordsworth. This approach is taken by Andrew Bennett in his recent study, Wordsworth Writing. Bennett concentrates his discussion of "scriptural or writerly violence" on Home at Grasmere DC MS 28, allowing for material complexity in the relations between the two texts, so that Wordsworth's defacement is also seen as a form of "quibbling" with Coleridge in which "this interplay of printed and handwritten text involves a form of aleatory or even 'unconscious' revision of Coleridge's poem". ${ }^{25}$ The focus on DC MS 28 probably occurs because Bennett's account draws upon Raimonda Modiano's interpretation of the text of Home at Grasmere and her argument for a displaced sacrificial violence held within the poem, as well as Paul Magnusson's reading of the text in terms of a shift in relations between Wordsworth and Coleridge in $1800 .^{26}$ Modiano reads the absence of the two (male) swans from Grasmere as a deliberate writing-out of Coleridge from Wordsworth's life at this time:

There is no room for Coleridge in Grasmere . . . . In order to inhabit a new world and become its owner, Wordsworth must dispense with, i.e. symbolically kill, his literary rival. (510)

However, exactly the same argument of material violation could be made for "Michael" in DC MS 30, so that it is surprising that neither Modiano, (who does not analyse manuscript materials at all), nor Bennett, use the "Michael" manuscript, which would appear to strongly reinforce a reading of violent appropriation (of “Christabel” by “Michael”, Coleridge by Wordsworth). From such a perspective, well-known public

25. Andrew Bennett, Wordsworth Writing (Cambridge: Cambridge University Press, 2007) 95, 97. 26. See Raimonda Modiano, "Blood Sacrifice, Gift Economy and the Edenic World: Wordsworth's 'Home at Grasmere'," Studies in Romanticism 32 (Winter 1993): 481-521; and Paul Magnusson, Coleridge and Wordsworth: A Lyrical Dialogue (Princeton University: Princeton University Press, 1988). Modiano follows Magnusson in reading Home at Grasmere as a poem which "attempts to create a ground for his poetry elsewhere than in his dialogue with Coleridge" (Magnusson, 230). 
acts of "usurpation" concerning the marginalisation of Coleridge's work in the 1800 edition are anticipated and performed in the manuscript space. I want to problematise such a reading, however.

In Andrew Bennett's account (and to some extent in my own as outlined above) the primary textual place and space of the printed book is displaced by Wordsworth's creative act which transforms the identity of the place in which it is entered. However, a number of points against this reading need to be raised. It is worth bearing in mind that Coleridge, by interleaving his own copy, had already re-defined the nature of the object, turning it from a stable published collection into poems awaiting revision and annotation. ${ }^{27}$ Equally, an argument that Wordsworth is aggressively inscribing himself over Coleridge's words is not fully borne out when we look carefully at entry into both manuscripts (DC MS 28 and 30). Wordsworth's base entry, as already discussed, is predominantly entered first on the blank interleaved pages, with the printed pages largely containing overspill material, rather than being a deliberate focus for "bibliographical graffitti" (Bennett, 90). What I am also trying to suggest in this section of the paper is that the textual and material argument (as well as an understanding of the complex relationship between the two men) deepens if we take into account the full materiality of the manuscripts and of the relationship between "Michael" and Christabel understood across the entire production of "Michael". We know that "Michael" was a text that Wordsworth was finding difficult to take forward so that it is possible that the textual presence of Coleridge helped to overcome these difficulties. It is at least as plausible, then, that the physical and spatial juxtaposition of Wordsworth's draft text with Coleridge's print is undertaken as a kind of enabling strategy, or as a competitive spur to composition, rather than in a destructive spirit. In other words, rather than one textual place and space being usurped by another, the two are vitally bound together, the first bringing the second into existence and re-making the physical object into a remarkable material intertext in which one textual place ultimately contains two interwoven textual spaces. Equally, although our initial sense is that Wordsworth's draft

27. In "John Stoddart, 'Michael' and Lyrical Ballads" Ariel (1970): 7-22, Robert Woof further speculates as to whether "Wordsworth began drafting in that book after he went, without Dorothy, to stay with Coleridge on 15 November" (15). If this were the case it could even mean Coleridge gave Wordsworth the copy specifically for the writing of "Michael". There is no firm evidence for this, however. 
displaces the printed text (encouraging us to privilege the former and overlook the latter) this really does depend on how we choose to read the manuscript page. If we allow each manuscript page its full spatial and material meaning then the textual place and space of each entry can inform each other. A brief example will illustrate my meaning.

In the final pages of DC MS 30, where Wordsworth is describing the movement of Michael and Luke across the hills and valleys in search of a lost sheep (as part of what later became "The Matron's Tale"), points of meaningful conjunction between printed and draft text strike the eye on more than one occasion (see illustrations). So, on $27^{\mathrm{r}}$, Coleridge's printed text describes the failure of Persuasion to "lure the fleet-wing'd Travellers back again" in the context of a sonnet about the loss of hope, whilst on the following page $\left(27^{\vee}\right)$ the first Coleridge line begins memorably, and rather romantically, "Pale roamer thro' the Night!" in a poem which is actually a description of a prostitute. As a reader, working with Wordsworth's draft, certain lines or images of the printed text stand out and one responds to those lines in an independent context on the page without reading the entire poem to which they belong: the handwritten text asserts itself over the printed words but the latter still catch the eye. When Wordsworth chooses to enter his text on the printed page it seems possible that this same kind of partly de-contextualised response occurs. As a writer, re-reading but also actively entering text, this allows the possibility of a kind of "intertextual bleeding" that feeds into creativity. So, whilst it is clear that Wordsworth is not reading every line of Coleridge's printed texts he might be indirectly responding to a single line, taken out of context, as he composes over it, subconsciously reading as he writes. In this way then, the prior textual place is directly bound up with the new making of the poem written over or around it.

Across both of the pages mentioned above, with their description of "Travellers" and "Roamers", at top and bottom there also runs a description of Michael and Luke roaming the hills, and passing rapidly across the Lake District landscape (see illustrations):

ills

Which northward did they pass

by arthurs [?chair]

And fairfields highland highest

[?hill] 
on the

(DC MS 30, 27 )

to Gris

Leaving St Sundays crag from fair

They shot, \& up to that cloud loving

fond

Seat Sandal that $\{[$ ?glad] lover

of the clouds

And that sharp mountain with his [?famous]

That hill yet was link'd [?with]

(DC MS 30, 27 $7^{\mathrm{v}}$

For the Wordsworth drafts, the text enacts its meaning materially and spatially as his "Travellers" shoot on across the printed page, entered in a loose and rapid hand. In contrast, on these pages the Coleridge poems present us with vertical, fixed, "Effusions" - stable upwellings from the poetic ground. Here, then, the relationship between the printed book and the handwritten text appears to be harmonized. Wordsworthian draft runs in horizontal counterpoint, creating a physical and spatial dialogue within the manuscript. We could even go so far as to interpret the Coleridgean printed text as offering a kind of visual and formal support and steadiness that enables the rough draft to come into existence around it. At the same time, at a level of content the two textual spaces seem also to be in a different kind of dialogue. On this page, the outcast prostitute wandering the streets of the city is offset and framed by the healthy outdoor ramblings of the natural man.

I have considered two different ways in which personal tensions appear to be played out in the textual and material spaces of the "Michael" mss. One final manuscript example needs to be mentioned. The Printer's Copy, sent to Biggs and Cottle on $18^{\text {th }}$ December, is made in the hand of none other than Samuel Taylor Coleridge (and Sarah Hutchinson). Coleridge thus undertakes to copy out the actual lines which, when set into 
print, will finally, empirically, supplant his text within the volume. How do we understand such an act? It suggests either that there was no real tension over the textual replacement at the time - that the production of the 1800 Lyrical Ballads, the writing, the copying, decision-making and negotiation with proofreader, printers and publishers was truly undertaken jointly. Within the "now" time of its making, which the material object asserts so strongly, "Christabel" had not been "rejected" but put aside for publication elsewhere, (with "The Pedlar" or on its own) and Wordsworth and Coleridge were merely two friends under pressure working hard to meet a tight deadline. ${ }^{28}$ Alternatively, it suggests an almost pathological degree of self-abasement by Coleridge and a total lack of consideration by Wordsworth. All we know for certain, is that in terms of textual place and space, it directly involves Coleridge in the filling of the space laid aside for his own poem by the writing out of Wordsworth's words, in his hand.

Finally, if we turn away from the physicality of the manuscript materials to Wordsworth's difficulty in writing "Michael" a different kind of spatial relationship emerges for this poem: one between body and world, textual place and geographical place. Dorothy's detailed records reveal the extent to which the act of composition appears to be tied to an actual (geographical) location for this text:

Wm again composed at the sheep-fold after dinner ... [October $15^{\text {th }}$ ] (Journal 27).

A very fine October morning. William worked all the morning at the Sheep-fold but in vain. [October $18^{\text {th }}$ ] (27).

Monday $20^{\text {th }}$. William worked in the morning at the sheep-fold. (28)

Tuesday $21^{\text {st }}$. William had been unsuccessful in the morning at the sheep-fold. (28)

28. In a letter to Humphrey Davy of $9^{\text {th }}$ October, Coleridge tells him "We mean to publish the Christabel therefore with a long Blank Verse Poem of Wordsworth's entitled the Pedlar" (631) although by December $2^{\text {nd }}$ he states: "I purpose to have Christabel published by itself"(Collected Letters of Samuel Taylor Coleridge, ed. Earl Leslie Griggs [Oxford at the Clarendon Press, 1956]), 649. Wordsworth writes to Thomas Poole in April 1801 that: "Christabel is to be printed at the Bulmerian Press, with Vignettes \&c \&c I long to have the book in my hand it will be such a Beauty" (Letters: EY 324). 
Wednesday morning $\left(22^{\text {nd }}\right)$. Wm composed without much success at the Sheepfold. (28)

Sunday. W. burnt the sheep fold - a rainy night. [November $9^{\text {th }}$ (31) Dorothy's last entry for this phase of composition - "W burnt the sheep fold" - is particularly interesting in terms of place and space within compositional process since (as various commentators have noted) it clearly refers to the material text, and not to the stones of the actual sheepfold in the valley that she and William sought out. Retrospectively we realise that when she writes of Wordsworth working "at the sheepfold" it is frequently unclear whether William is physically out at Greenhead Ghyll or whether she is simply describing his work on the manuscript text. ${ }^{29}$ For the purposes of this paper, however, the fact that early work on the poem is clearly referred to as "the sheep fold" means that actual, textual, imaginative and symbolic identities of the core object are conflated (in a highly Wordsworthian way) during the process of composition. As the critic, Susan Eilenberg, points out, Dorothy's remarks "suggest the equivalence of words and things". 30

The importance of the sheepfold as an empirical touchstone, validating poet and poem by connecting the writing of them directly to what they represent, (connecting geographical, imaginative and literary space) should not be underestimated as a core element of Wordsworthian pastoral poetics. In an unused lyric fragment found in "Michael" DC MS 30 the poet describes wandering amongst the mountains until he finds himself in:

some spot like this

Shut out from man some region one of those

That hold by an inalienable right

29. It would be misleading to conclude from this, as Andrew Bennett seems to suggest, that whenever Dorothy writes of the sheepfold "she means, in all probability, that he is working 'at' the poem" (Wordsworth Writing 39). In a later entry for $11^{\text {th }}$ November, Dorothy notes: "William had been working at the sheep-fold. They were salving sheep" (31). Here it is clear that Wordsworth is outside, although without the subsequent comment it would read like any of the other entries. In other words, many of the preceding entries could be either an unspecified geographical, or a textual, reference. Mark Reed judiciously notes that: "DWJ's 'sheep-fold' may well involve a geographical location; but the general manner of use of the phrase ... leaves little doubt that DW is referring consistently to a poem" (CMY 91).

30. Eilenberg, 90. See also her comment that: "An almost organic relationship between objects and their meanings characterizes even the difficult composition of the poem"(89-90). 
And independent life and seem the abode

Of nature \& of unrecorded time

If looking round I have perchance perceivd

Some vestiges of human hands, some steps

have been

Of human passion, they to me are sweet

t\}

As light a [s]\} day-break, or the sudden sound

Of music to a blind mans ear who sits

Alone \& silent in the summer shade.

\{They

\{ It are as a creation in my heart.

I look into past times as prophets look

to

back

In the futurity ... (DC MS $304^{\mathrm{r}}$ )

This seems to me a revealing account of the Wordsworthian relationship to landscape, with its idealised presentation of the poet as prophet of the past, recuperator of lost stories, and, of course, with the anticipation of the piled-up stones of the sheepfold in "Michael" as "vestiges of human hands". In the context of the imminent publication of a manifesto for an expressive poetics, and one which seeks to "follow the fluxes and refluxes of the mind when agitated by the great and simple affections", this passage underlines the spatial nature of that poetics as played out in the second "pastoral" volume of Lyrical Ballads (1800). Objects provide the vital intersubjective point of connection through the "human space" that clings around them. However, rather than simply pointing towards a storied landscape these objects also seem to have an active power: "They are as a creation in my heart". The metaphor itself expresses the metaphoric force of such transforming objects. On the next manuscript page, the experience described here is itself transferred from poet to character by means of a hypothetical conversation with Michael:

And if it was his fortune to converse 
With any who could talk of common

In an unusul[?] mind and give to them

or

Unusual[?] aspect and by questions apt

[?Reason] the [?purpose ?In ?particular ?sort]

\{that

Wake sudden recognitions $\{[$ ? ] were like

t\}

Creations in [?]\} he mind \& were indeed

Creations ... (DC MS 30, 4 ${ }^{\mathrm{V}}$ )

Now, the knowing poet (or one who stands for him) awakens an imaginative response through speech about the landscape, turning "common things" into creations.

Neither of these passages is taken forward into the later drafts of the poem but both of them correspond to the account of Wordsworth's declared intentions for "The Brothers" and "Michael" in letters to Charles James Fox and Thomas Poole. Wordsworth's wellknown metaphorical conversion of the "tract of land" into "a tablet upon which they [domestic feelings] are written", then into "objects of memory" and finally, of course, into the receptacle of the poem, sets up a sequence of spatial and temporal exchanges that the earlier poetic account had also explored for both the poet and the ordinary man. This ideal, of radiating meaning, also seems to inform the well-known account of Wordsworth reading the poem to Coleridge: "on this blessed calming Day - sitting on the very Sheepfold dear William read to me his divine Poem, Michael. - The last day of the year". ${ }^{31}$ The careful choice of time and place loads the reading with a place-specific meaning, seeking to make it, like the stones themselves into "objects of memory".

One other larger spatial context asserts itself throughout "Michael" and that is the presence of the poet Wordsworth living in the valley, Grasmere, and trying to write himself into that community throughout his first year of inhabitation. ${ }^{32}$ The material

31. The Notebooks of Samuel Taylor Coleridge, ed. Kathleen Coburn (London: Routledge \& Kegan Paul, 1957) Vol. I, entry 1782.

32. Peter Manning emphasises the personal value of the tale to Wordsworth at this time: "Michael is a structure through which Wordsworth asks questions central to his life" (Reading Romantics: Text and Contexts [Oxford: Oxford University Press, 1990] ) 36. See also Robert Woof's observation that: "If Wordsworth was projecting forward to future 'youthful poets' . . . he was also exploring links between his own past, with Ann and her tales at Hawkshead, and his present chosen life at Grasmere" (15). 
connection of "Michael", DC MS 30, to Home at Grasmere, DC MS 28, reminds us of this, but we should also bear in mind that Wordsworth's note to "Michael" makes an explicit connection: "The character \& circumstances of Luke were taken from a family to whom had belonged, many years before, the house we lived in at Town-End, along with some fields and woodlands on the eastern shore of Grasmere" (LB 400). The direct linkage of Michael's home to that of Wordsworth, further binds the poet's own uncertain ambitions for his poetic offspring, sent from this place out into the world, to that of Michael's for his son. The failed generation of Michael's own descendants is hopefully to be replaced by future generations of readers of Wordsworth's poem: "The shattered covenant between the eighty-year-old Michael and the eighteen-year-old Luke is succeeded by the compact between the narrator and his heirs". ${ }^{33}$

\section{Spatialised Speech Acts: Michael's Covenant}

Thus far I have tried to illustrate the ways in which the material and spatial nature of the compositional process bear upon our understanding of "Michael", but they have done so without directly informing interpretation of the poem itself. What I want to do now, is to analyse the significance of the spatialised speech act which lurks at the heart of "Michael", doing and undoing the poem's meaning from within. In his analysis of the poem, Peter Manning comments that: "To account for the moving power of the story, [however,] is not easy: the final effect on us is greater than analysis of its naturalistic texture can explain" (35). My aim here is to try to offer such an explanation through an understanding of the spatialised speech act.

It is worth remembering that in The Practice of Everyday Life, Certeau's definitions of "place" and "space" occur within the context of a description of "spatial stories". As one of the motivating forces that bring space to life, stories are of great importance. They "carry out a labour that constantly transforms spaces into places or places into spaces" (PEL 118). Certeau defines stories as an essential "way of operating" which are both spoken and spatially experienced. For him "every story is a travel story - a spatial practice" (PEL 115). Similarly, Henri Lefevbre describes "representational space” as

33. Manning, 48. 
“alive, it speaks. It has an affective kernel or centre”34 (Production of Space, 41-42).

More negatively, the loss of a story results in a diminution: "where stories are

disappearing ... there is a loss of space" (PEL 123).

In the founding text of speech act theory, How To Do Things With Words, J. L.

Austin describes how:

Saying something will often, or even normally, produce certain consequential effects upon the feelings, thoughts, or actions of the audience, or of the speaker, or of other persons: and it may be done with the design, intention, or purpose of producing them. $^{35}$

Austin describes such "consequential effects" as "perlocutionary" (101) - that is, emotional, felt, acts which exist beyond the locutionary and illocutionary nature of the utterance itself, although occurring as a consequence of it. Certeau's analogic use of the structure of the speech act seems to be partly located here, focussing as it does on the internalised effects of acts as much as the acts themselves. In particular, the function of the story as a spatial speech act brings with it the likelihood of a perlocutionary force acting upon either teller or listener, or both. This force becomes particularly significant when we turn from actual stories, experiences occurring as we walk through the world, to written, spatial stories. At a level of poetic representation the success or failure of a spatialised speech act can have powerful ramifications ("consequential effects"). I want to explore these now in relation to "Michael".

Michael's is a situated existence. He is defined in the context of "these fields, these hills / Which were his living Being even more / Than his own Blood" (lines 74-76). ${ }^{36}$ The dramatic strength of the poem relies upon the revelation that what seemed most solid about that existence - the recognised symbol of his and Isobel's lit cottage in the valley; the known range of his lands; the familiar weight of things around him - is capable of absolute dislocation and dematerialization: "The Cottage . . . Is gone, the ploughshare has been through the ground" (lines 485-86). At the heart of this lost story, and in part the cause of it, is the covenant made between Michael and Luke at the

34. Henri Lefevbre, The Production of Space REF 41-42.

35. J. L. Austin, How To Do Things With Words (Cambridge, Massachusetts: Harvard University Press, 1962) 101.

36. All quotations from Michael are taken from the Reading Text in the Cornell edition of Lyrical Ballads. 
sheepfold, an explicitly spatialised speech act, and ultimately a failed speech act, which is worth close attention. ${ }^{37}$

The OED defines a "covenant" as: "A mutual agreement between two or more persons to do or refrain from doing certain acts; ... . sometimes the undertaking, pledge or promise of one of the parties". In How To Do Things With Words, Austin outlines five classes of speech act for which that of "covenant" falls into the category of "commissives". He tells us that, "the whole point of a commissive is to commit the speaker to a certain course of action" (157). It is a speech act with an unusually strong force. ${ }^{38}$ However, the $O E D$ definition suggests that a "covenant" may not be an entirely mutual act, and this is strongly supported by biblical examples. In giving Moses the Ten Commandments, God declares "if ye will obey my voice indeed, and keep my covenant, then ye shall be a peculiar treasure unto me above all people". ${ }^{39}$ Similarly, God instructs Abraham: "This is my covenant, which ye shall keep, between me and you and thy seed after thee". ${ }^{40}$ In both cases one (dominant) party makes the covenant and the other has little choice but to keep it. Something of this is surely felt in the covenant between Michael and Luke, a relationship which (as many critics have noted) also bears a strong resemblance to that between God, Abraham and Isaac. ${ }^{41}$

The visit to the sheep fold, before Luke's departure, initiates an unusually long speech by Michael. After a brief recollection of their lives together, he pauses, points "to the stones near which they stood" (393) and continues:

"This was a work for us, and now, my Son,

It is a work for me. But lay one stone,

Here lay it for me, Luke, with thine own hands.

37. As Andrew Bennett has pointed out, Wordsworth's poetry is often concerned with "conversations that fail" (Wordsworth Writing, 104). In fact, he goes so far as to suggest: "Wordsworth's poetry is a redefinition of 'poetry' as a site of communicative or conversational or dialogic faltering, disturbance, failure or collapse" (105). See also John P. Bushnell, "Where is the Lamb For The Burnt Offering: Michael's Covenant" Wordsworth Circle 12 (1981): 246-252, who states that: "This poem, after all, dramatizes not only covenants, but broken covenants" (248) and Peter Manning who describes "Michael" as "a tale of broken covenants" (35).

38. John Searle, in Speech Acts: An Essay in the Philosophy of Language (Cambridge: Cambridge University Press, 1969), reminds us that phrases such as "I promise" are "among the strongest illocutionary force indicating devices for commitment provided by the English language" (58).

39. Exodus 19:5.

40. Genesis 17:10.

41. See LB 401-402. 
I for the purpose brought thee to this place."

(Lines 395-398)

As Michael makes clear, the sheepfold ought to stand for their joint life and purpose, it ought to be merely one ordinary object amongst many in their daily routine. However, in this reappropriative act, it becomes something far more monumental and Luke is asked to lay "the corner stone" (414) as Michael declares:

"let this Sheep-fold be

Thy anchor and thy shield; amid all fear

And all temptation let it be to thee

An emblem of the life thy Fathers liv'd ..."

(Lines 417-420)

The laying of the stone as a last shared event is itself an explicitly spatialised speech act fixed in that spot by Michael: "Lay it for me Luke . . . I for the purpose brought thee to this place". ${ }^{42}$ Soon after this, the idea of a covenant is explicitly introduced, although in a highly ambiguous way:

"When thou return'st thou in this place wilt see

A work which is not here, a covenant

'Twill be between us - but whatever fate

Befall thee, I shall love thee to the last

And bear thy memory with me to the grave."

(Lines 423-427)

What appears to stand as a "covenant" then, is the presence of the not-yet-built sheepfold as "A work which is not here". In other words, a covenant both has and has not been made.

We need to recall that a covenant is an agreement - verbal or written - but not an object - as emphasised in Genesis when the rainbow stands as "a token of a covenant between me and the earth". ${ }^{43}$ We might expect the token of a covenant to stand as a mutual sign between the two parties: that is, the rainbow appears in the sky to remind

42. In Austin's terms it is an "exercitive" by which "others are 'compelled' or 'allowed' or 'not allowed' to do certain acts" (155). Reeve Parker, in "Finishing off 'Michael': Poetic and Critical Enclosures," Diacritics 17.4 (Winter 1987) 53-65, also discusses the "vocative thicknesses" of the poem in which "Michael's vocatives deliver a summons" (53).

43. Genesis 9:13. 
God not to flood the earth, and to remind Noah and his descendants to live good lives. However, this does not appear to be the case. Rather, God declares "I will look upon it, that I may remember the everlasting covenant between God and every living creature". ${ }^{44}$ Even the token, then, has a one-sided function. ${ }^{45}$ In particular, it is the need for an "everlasting covenant" that brings about the need for a token, ensuring that the covenant is even more one-sided for future generations, who are bound by it whether they like it or not. Technically speaking, then, the (unbuilt) sheepfold can only be a token of a covenant. But if the sheepfold functions as a token, it still remains unclear what the actual covenant is. What absolute commitment has Michael made? At first, the end of Michael's speech might appear to be his pledge, an assertion that his love for Luke is absolute. But that assertion also seems, rather oddly, first to undermine the covenant which preceded it and then to undo itself, since, whilst it asserts his love, it also implies no possibility of an unsuccessful return for Luke.

The covenant is supposed to function in such a way as to successfully commit Luke to the course of action agreed upon, but instead of an absolute promise to be kept, it operates as a promise yet to be made. ${ }^{46}$ This further raises the problem of how Luke is to "keep" such a covenant and what is expected of him. He would appear to be bound by Michael's speech, insofar as Michael's ability to build the sheepfold depends upon his ability to return and save the land, but the confusion inherent in the way Michael articulates and employs the covenant leads me to wonder whether it is, in fact, truly with Luke at all. Michael has two loves: his land and his son, and to some extent one stands for the other. ${ }^{47}$ Given the choice of parting with a portion of land or Luke, Michael chooses Luke:

the land

44. Genesis 9:16.

45. The token of circumcision made with Abraham also concerns the need for an "everlasting covenant" that can be passed on to future generations. Here, the token is literally embodied: "my covenant shall be in your flesh for an everlasting covenant" (Genesis 17:13) but it also functions (as the rainbow does not) as a recognisable sign of difference, allowing God to identify his people.

46. John Bushnell concludes that: "The structure symbolized a covenant between father and son, but . . . that covenant never truly existed to begin with" (252).

47. In his letter to Thomas Poole, April $9^{\text {th }}, 1801$, Wordsworth comments of such men as Michael (whom he also identifies with Poole) that: "I have attempted to give a picture of a man, of strong mind and lively sensibility, agitated by two of the most powerful affections of the human heart; the parental affection, and the love of property, landed property, including the feelings of inheritance, home and personal and family independence" (Letters: EY 322). 
Shall not go from us, and it shall be free,

He shall possess it free as is the wind

That passes over it. (Lines 254-257)

Luke must go from them, in order for the land not to do so.

From the start, God's covenant with Abraham concerns both the land and the future race: "the Lord made a covenant with Abram, saying, Unto thy seed have I given this land". ${ }^{48}$ Just as in "Michael", then, Abraham is bonded for the land and its future inhabitants, his descendants. By proving himself willing to sacrifice Isaac, and thus apparently to give up that future, he is rewarded. However, when we compare him to Michael, as John Bushnell points out:

between Abraham's covenant and Michael's covenant there exists at least one fundamental difference. Abraham answers to an outside power, his God. He does not choose to sacrifice the son of his old age; he submits instead to a decree from an absolute source. (250).

The only reason Michael sends Luke out, is because he is himself "bound / In surety for his Brother's Son" (220-221). Thus there is a sense in which Michael's second binding of his son (previously bound "only by links of love" [412]) looks very much like an act of displacement, attempting to make good a first loss, through a second, and shifting the failure of Michael to keep his own covenant with the land, to Luke's failure to keep the covenant with him.

The fact that the speech-act is also spatialised now emerges as a significant element for the poem's larger meaning. Not only is the utterance located in a chosen setting, one representative of their life together, but the sheepfold also stands metonymically for that way of life, and for the land on which it is located. The spatialised nature of the central speech act exemplifies the nature of the three-way relationship between Michael - Land - Luke in which, for each living being, the identity of the other person, as well as the relation between the two of them, is bound up with a particular place and an obligation to it. However, Michael's speech act appropriates a space previously shared by both speakers and belonging to both, and gives it a new identity which, ironically, destroys, instead of reaffirming, its previous value. This is made clear when the sheepfold's

48. Genesis 15:18. 
function as symbolic token increasingly comes into conflict with its primary identity as a thing of use, ("the Fold of which/ His flock had need" [470-471]), which Michael is no longer able to complete. The spatialised nature of the speech act - the power of words in a particular place, tied to a particular object, ultimately has the opposite effect of that intended by the speaker at a dramatic level and the "perlocutionary force" is powerfully inverted.

Crucially, however, the simultaneity of different kinds of space, held within the intersubjectivity of the literary work of art, allows for the recuperative power of narrative and memory to assert themselves, for the "lost" space to be reclaimed by writer and reader. This is where the poem "Michael" emerges as a remarkable example of the power of the spatial reading to move freely across different kinds of space (geographical; material; narrative; textual; writerly; readerly). The poem was always a retold tale. From the start it presented itself as an oral narrative, here written down for the sake of future readers. It was introduced as part of the fabric of life in a region where tales are woven together, ensuring that something survives and shapes the lives of those who hear it. At the same time, the function of the poet-narrator is to connect those with no knowledge of the geographical location to a specific spot by direct address to them. At a level of narrative, then, the poem returns the reader to a specific location for the introduction of Michael's speech to Luke:

Near the tumultuous brook of Green-head Gill

In that deep Valley Michael had designed

To build a Sheep-fold" (Lines 332-334)

This is also a return to the context established at the start of the poem by the poetnarrator, directing us towards both place - "Up the tumultuous brook of Green-head Gill" (2) - and humanised object, "a straggling Heap of unhewn stones: / And to that place a Story appertains" (17-18). In narrative terms, the telling of the speech act functions as an act of delayed gratification for the reader: the relating of a promise unfulfilled, fulfills the narrative promise. The text and the telling of it deliberately conflate spatial and temporal layers and these easily extend further beyond the level of content once we know (as we do) about Wordsworth's writing and reading of the poem in that place. 
This piling up of layers of spatial significance for the poem, in the text and in the world, ultimately allows for an all-important double appropriation of place by the literary speech act: first at a level of content and then in terms of what the poem does (or wants to do) for the poet and for its first, and subsequent, readers. ${ }^{49}$ In other words, the poem itself now becomes a kind of spatialised speech act, a performative event, connecting poet and future readers as "interlocutors" through the medium of both a spatially and temporally free text and a place-specific geographical location (the valley of Greenhead Ghyll). Literature has the power to take the "force" which was part of a fictionalised, poetic, speech act and redirect it, translating one kind of response to place into another, now charged with moral force and ultimately directed out towards the reader - "this is the Tale that moved me and I tell it that you too will be moved". For the poem to succeed, the speech act within it must fail.

The Map and the Tour: Journeying through "Michael"

In the final part of this paper I want to begin to consider how we, as readers, inhabit "textual space", particularly in relation to the less negotiable terrain of the text in a state of process. I want to develop Michel de Certeau's suggestion that the analogy between walking and speech acts could also "extend to the relations between the acts of writing and the written text" (PEL 98).

Certeau's distinction between a total grasp of spatial organisation and the experience of the individual moving within space emerges clearly in the account he give of two responses to a request for oral directions in New York City. These two everyday ways of conceiving space - as "map" or "tour" - correspond to the distinction between an apparently total vision which nonetheless deceives, and a lived experience which can be understood only locally. Oral descriptions of how to get somewhere (itineraries) employ spatialised speech acts. That is, they re-enact the individual experience of moving through a certain space for the user "You turn right", "You turn left" and so on. By contrast the geometrical space of the map seeks to assert a totalising overview, drawing

\footnotetext{
${ }^{49}$ Clearly, there is a danger here of interpreting the poem's double covenant (failed/ recuperated) in the idealised terms that the poet projects. We are of course free to reject the spatialised strategies it seeks to create.
} 
upon an external perspective. Certeau distinguishes between "seeing (the knowledge of an order of places) or going (spatializing actions)" (PEL 119). Historically, Certeau argues, the creation of the map came about out of itinerant experiences and the two were vitally connected. $^{50}$ Over time, however, the map detached itself from its origins and became dominant as an abstract geometric representation of space. Maps thus become "proper places in which to exhibit the products of knowledge" (PEL 121). By contrast oral stories about space, create space, constantly asserting different ways of moving through it so that "what the map cuts up, the story cuts across" (PEL 129).

The distinction between "map" and "tour" and the way in which we move between these two modes of conceiving space, is particularly useful when we turn from the mapping of lived space to try and think about the way in which we as readers inhabit or move through literary works, both in their published and draft manifestations. I want to suggest that when we read we integrate these two ways of experiencing space so that map and tour vitally inform and define each other. If we use the analogy of a walk we can identify three main ways in which the distanced perspective of the map and the experience of the itinerary route are connected. Before walking, the map is consulted as an act of imaginative projection - to decide on a route but also to make estimates about distance, velocity and so on, based on the geometrical information provided. At this point the map requires imaginative anticipation of place. During the walk, the map is likely to be repeatedly consulted but the simplified and ordered representation of the world that it presents is now used directly in relation to geographical place and bodily situatedness in an active integrated way. The degree to which, we rely upon it also directly informs and affects the nature of the lived experience. So, for example, the user may decide deliberately to walk without a map or may know the place so well that no map is required. In both of these cases the absence of a map radically redefines the nature of the tour since the individual has either rejected the totalising view altogether, or draws upon internalised prior experience (cognitive mapping). Finally, after the walk, having returned safely home, the map may be consulted again, in a retrospective

\footnotetext{
${ }^{50}$ It is true that very early maps often used the form of a written or mapped itinerary (places along a route). The Roman Peutinger Table is a famous example. However, the ability to adopt a plan view and draw to scale was also mastered by the Romans and even by the Mesopotamians in 2000 BC. REF Historically, the relationship between geometric abstraction and direct experience of travel is more complex than Certeau suggests.
} 
revisiting of the experience. The user is now able to lay human space over geometrical space so that when he or she looks "at the map" much more than the map is being seen.

The dynamic interaction of map and tour (of geometrical and human space) in our experience of the physical can be directly compared to textual place and space in relation to printed or manuscript texts. If textual place exists as the site to be negotiated (corresponding to physical space) then both "map" and "tour" would seem to apply to textual space, and to the reader's two different ways of moving through it. ${ }^{51}$ For the published work, the establishment of a safe textual place, easily "seen” is provided by spatially organising elements - contents page, chapters, page numbers, the fact that the text runs from front to back in Western culture, and so on. For the most part, as readers, we take such "mapped" elements for granted since they allow us to move rapidly into an experience of textual space which asserts itself over textual place (unless the text deliberately plays with such concepts by confronting our expectations). ${ }^{52}$

If we turn away from the mapping of, and movement through, the published text to manuscript material, a very different kind of reading-as-mapping occurs and we also have to allow for the writer as his or her own reader of the work-in-the-making. The manuscript object as a textual place relies on mapping in ways that a printed book does not - in part because the place itself does not already contain the obvious features that enable us to negotiate it easily. This means that the reader of the manuscript text requires self-location to a far greater extent than the reader of a completed work. The reader first needs to find his or her bearings, understanding relations between the manuscripts for a single text or the nature of entry for a notebook. Here, the "map" is provided by the process of editing and presenting scholarly materials, transcribing, creating "reading texts" for drafts (creating a 'proper place' out of the chaos). In the case

51. The map, then, is provided by the scholarly edition (which often features visual representations of the content of a notebook) whilst the itinerary is self-created.

52. In this discussion I am largely using the idea of mapping in a metaphorical way. However, rich potential for future spatial analysis lies here in terms of the extent to which a literary work deliberately draws the reader's attention to its own spatiality, at a level of content, or through deliberate disordering of expectation or through explicit geometricality (for example, publishing a map in front or back covers). See also Franco Moretti, Atlas of the European Novel 1800-1900 (London: Verso, 1998) and Graphs, Maps, Trees: Abstract Models for a Literary History (London: Verso, 2003). Moretti aims to use maps "not as metaphors ... but as analytical tools" (Atlas 3). 
of Wordsworth, the Cornell editors are the map-makers. ${ }^{53}$ The "tour" can only come later, applying to the reader's movement through the developing text as process, enabled by the scholarly superstructure. In part this problem of the mapping of manuscripts may explain the slow development of a fully interpretative genetic criticism in Literary Studies: only once the entire area is mapped can we begin to re-create the space for ourselves and fully inhabit it.

The itinerary or tour, the reader's personalised route through the draft material, differs from the map in that it is not concerned with reconstructing the order of a text's development or the relative location of the manuscript but with understanding and interpreting the making of meaning in multiple ways. Once an understanding of the map is in place, then the traveller through the text can begin to look around, notice recurring elements, identify unusual features, return to particular spots. Thus, there may be the negotiation of a single page or facing page, the entry of a block of work within a notebook, the comparison of the contents across a notebook, the tracing of a text across different notebooks and so on. The reader "inhabits" the writerly place by understanding the narrative of developing meaning that it presents at both micro and macro levels. In this way the textual space of the manuscript emerges as "a practiced place" (PEL 117).

For the writer, the distinction between place and space, map and tour, is far less clear. The later reader responds only to what is already there, but for the creative agent the map is still being made. Perhaps a loose analogy can be made here between the writer, journeying forward into the blank spaces of the notebook and the eighteenth-century cartographer, voyaging along unknown coasts, for whom the intricate curves and inlets of the known land ink forward into blankness. Place only fully comes into being with the marking of that place upon the blank sheet. Once it is there, others can easily follow it, but for the cartographer himself the map as it is being written has a different identity and function. The writer as reader of his or her own work brings about and participates in a unique reading, because it is a reading with the power to change the object being read. The creative temporality of the manuscript object continues to hold within it not so

53. Often the introduction to a Cornell edition will contain diagrammatic elements to explain the contents of a notebook. 
much an alternative map as an alternative textual and temporal state. In other words, it is a map which does not know where it is going; a map which draws itself.

For the later reader, draft materials are both object and place, a de-familiarised landscape of the known that we travel through and make our own. At the same time, however, the reader also reads through a filter of what is already known, drawing upon previous knowledge of the published work. Temporally, the reader needs to put aside knowledge of later outcomes, responding to the page in terms of the meaning it holds at the time it was entered. The result of this can be to reveal a very different "map of meaning" underlying the known land of the final published work. It compels the reader to suspend the retrospective perspective of what is already known (the text as it will come to be) and engage with the material anew. The manuscript of "Michael" (DC MS 30), re-visited here one final time, provides an excellent example of the way in which "textual space" for the unfolding poem in a state of process both differs from, and sheds light upon, the text in its published state.

It is interesting to note that, although there has been quite heated discussion over the relative ordering of mss for "Michael", there is surprisingly little debate over the fact that hardly anything of the poem's core symbolic meaning survives textually (except as Printer's Copy). ${ }^{54}$ This seems particularly ironic in view of the poem's concern with the power of the material object. The first draft manuscript of "Michael" (DC MS 30) does not contain any mention of interior cottage life, nor of the dramatic event at the heart of the published narrative; the bond which causes Michael to lose his land. Instead, as it exists in DC MS 30, the poem of Michael is about a total belonging: familial; social; topographical. It is focussed entirely on the relationship between father and son and on that relationship as it takes place within a certain landscape, the two being utterly intertwined. Above all, astonishingly, there is no mention or use of the sheepfold, in this manuscript or in the surviving fragments of DC MS 31, even though we know that this was a significant part of the poem's early composition and that the grounded object from which meaning emanates is central to the entire work and its underlying philosophy of sympathy.

54. I am referring to the Ariel debate of 1970-72. See $L B \mathrm{xv}$. 
The surprising absence of the sheepfold as structural and symbolic centre of the draft poem in DC MS 30 should not be taken to suggest that it is lacking in significance, however. Its very absence may draw attention to its importance at a compositional level. Exactly the same creative structure (of a non-existent core) occurs for a sub-narrative held within the "Michael" material for "The Matron's Tale". In this symbolic narrative, concerning Michael and Luke's search for a lost sheep, the heart of the tale (developed in DC MS 31) comes towards the end with the double leap of Luke onto an island in the flood and the lost sheep off it, followed by Michael's rescue of his son:

The sight was such as no one could have seen

Without distress and fear. The Shepherd heard

The outcry of his Son, he stretch'd his Staff

Towards him, bade him leap, which word scarce said

The Boy was safe within his Father's arms. ${ }^{55}$

In DC MS 30, however, this tale (anticipated by Dorothy's account of the walk up Greenhead Ghyll) never achieves its eventful narrative core but is written out in a way entirely descriptive and topographical, centred on the roaming of father and son over the hills behind Grasmere. Rough draft for "The Matron's Tale" is initiated in Dorothy's hand with the line "I will relate / One incident" (DC MS 30, 26 ${ }^{\mathrm{r}}$ ). However, no actual incident is related in this manuscript, as it survives. Instead, it is as if Wordsworth knows where the poem is going, but chooses to write himself rather meanderingly towards that point, which either provides compositional momentum or allows prevarication.

For "The Matron's Tale" this kind of movement is re-embodied twice over in the poem, semantically and graphically. At a level of meaning-production Michael and Luke, after much wandering, gradually draw closer to the physical location of the dramatic event in the represented landscape of the text. In material terms, the manuscript text also runs across the pages of the printed text towards this point in the narrative. At a larger level, too, the whole manuscript is characterised by an excess, as the writer seems to delay the inevitable, tragic events of the "Michael" narrative, in part

55. Mark L. Reed, ed. The Thirteen-Book Prelude by William Wordsworth (Ithaca and London: Cornell University Press, 1991) AB-Stage Reading Text, p. 219; VIII, lines 307-11. 
by developing "The Matron's Tale" within it - which, in turn, delays its own resolution. Wordsworth endlessly generates description rather than driving the narratives forward so that both major and minor narratives are ready to be re-directed, to be re-situated according to their dramatic centres. At the same time, as they are given here, in DC MS 30, they are "about" something very different. Does the fact that this is only early draft, and that the meaning is largely over-ridden (overwritten) in the final text mean that we need not concern ourselves with it, or does this early perspective compel us to view the later one differently? Should we seek to acknowledge the specific creative temporality that these materials assert?

In the case of "Michael" the spatial delays and de-centring of process do, I think, lead to an altered perspective on what is actually "central" to the completed work, as earlier critics have noticed. Reeve Parker describes the poem as "a text dearly gained by a process that left behind so many straggling passages and unhewn lines" and allows "the implication that in accident and looseness, rather than in purpose and work, might be the power of poetry, that form might stem from falling and dissolution". ${ }^{56}$ I would speculate further about the nature of Wordsworth's compositional avoidance for this poem. Intriguingly, a final stanza on the "Ballad Michael" draft pages does contain both an account of Michael sitting by the loose stones and Michael's words to Luke: "Then think of this sheepfold my Son let it be / A bond Thy Anchor and watch tower a bond between thee" (DC MS 15, 94 ${ }^{\mathrm{r}}$ ). It seems at least conceivable, then, that Wordsworth may have started the first problematic phase of composition for "Michael" by centring his creative energy on the central symbolic object but that, when this approach failed, he composed instead in a far less direct way which left the object unstated and circled round it. ${ }^{57}$

Understanding the way in which the poem shapes and directs itself in a state of process compels us to reconsider the shape and meaning of the text in its final state, and to read sections we might otherwise pass over rapidly. Reading the content of the manuscript in terms of what is there, rather than in terms of what we expect to find, or of

56. Reeve Parker 60, 63. See also Susan Eilenberg's account of the "self-thwarting narrative structure" (97). She writes of "the poem's narrative style which seems frequently uneasy about the events it has to relate and determined to get away with telling as little and as late as possible (94).

57. I do not mean by this that Wordsworth wrote a rhymed version centred on the sheepfold, then a blank verse version that evaded it. 
what we know to be there in the final text, is extremely illuminating. It reveals both those elements which are certain and present from the outset and those areas which cause the poet most difficulty. It does not necessarily begin or end where we would expect. It compels us to "re-map" the known text. If the writing of the poem is considered in terms of ground being covered, then what it reveals about textual space, delimited by the act of making, is a journey containing considerable retrograde motion as well as numerous false paths and byways. However, even this conceit is based upon a judging of the process of the text in terms of its final destination rather than for what it presents itself. What it actually represents is a different kind of journeying.

Ultimately, what I am suggesting in the final part of this paper is that the mapping of manuscripts is essential for the full reading and interpretation of manuscripts, as it is not for the completed work of art, and that one of the reasons that the wealth of facsimile and scholarly edited draft material (such as that of the Cornell Wordsworth) has not been opened up to full analysis is because of a tendency to overlook this dimension of the object and the need for the reader to use the map to develop his or her own itinerary.

The relation between textual place and textual space described throughout this paper could also be seen to interpret a Wordsworthian poetics of place in terms of the way in which all of us move between different spatial relations to the world. It relies, crucially, upon the intersubjective object - the thing in the landscape, the manuscript artefact, the literary text. For both writer and reader, and for an always-already-spatialised writer and reader (writing or reading in the world) active creative processes, of writing, of reading, of walking, like the use of a map, involve constant negotiation. The "user" must move between three different aspects of the object (by itself, in the world, re-visited); and the temporality of the object (before, now, after) as well as of imaginative projection (anticipatory; experienced; retrospective). These three dimensions apply to the writer making meaning, the reader interpreting meaning and the walker, journeying. All three undertake a conversion of space into place and back into space again and they perform this sequence over and over again in order to get somewhere. Sometimes they arrive where they thought they were journeying to and sometimes they do not. 


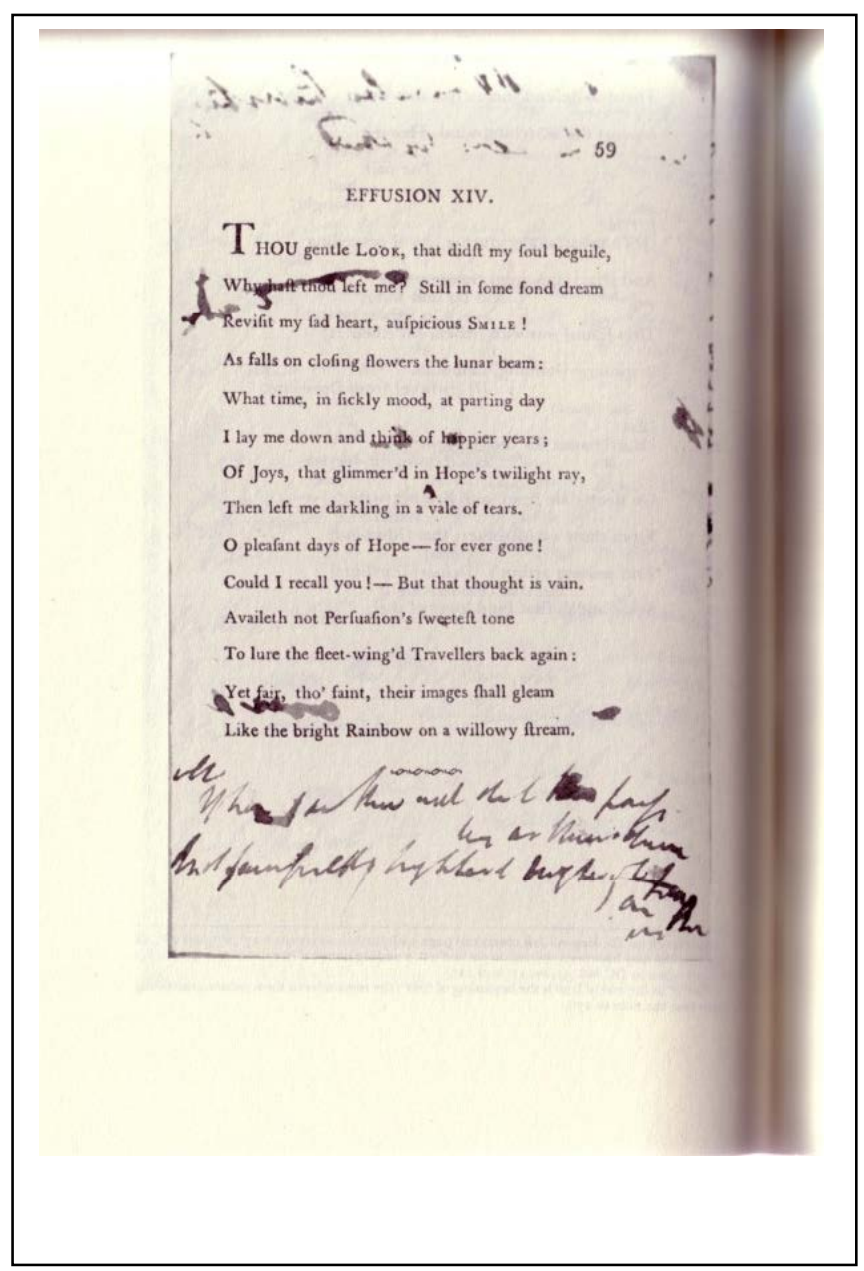

"Michael" DC MS 30, 27

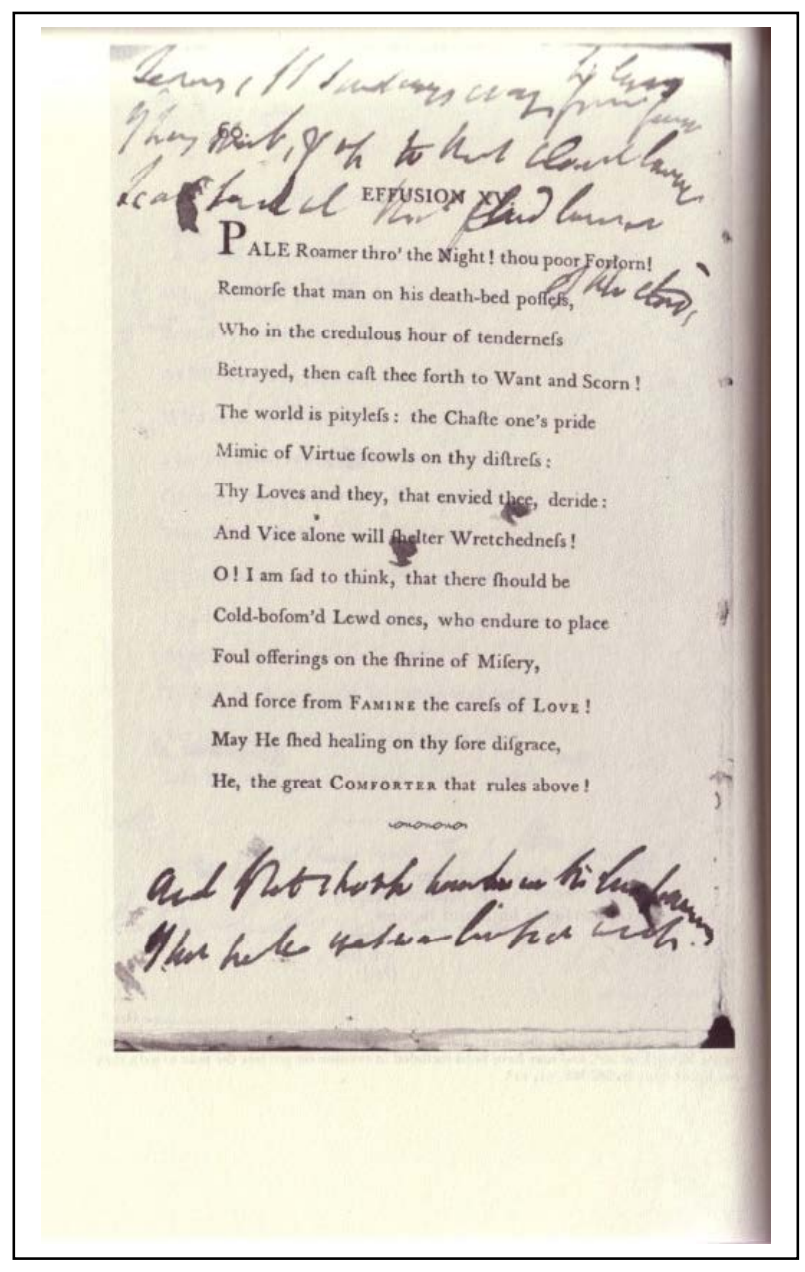

"Michael" DC MS 30, $27^{\mathrm{V}}$ 